\title{
ANALISA YURIDIS TENTANG PERJANJIAN DINYATAKAN BATAL DEMI HUKUM
}

\author{
Nanin Koeswidi Astuti
}

\begin{abstract}
Judge's decision which states that an agreement is null and void set forth in Article 1320 of the Civil Code, carry legal consequences of the agreement made by the parties, the agreement is no longer valid or hasnever been considered and restored to the original condition as in when the agreement has not been implemented. In practice, the judge gives the verdict declared the agreement null and void, because the requirements are not met the objective validity of a treaty that is about a particular thing and a cause that is not violate regulations.
\end{abstract}

\section{Kata Kunci: Perjanjian Batal Demi Hukum}

\section{Pendahuluan}

Perjanjian atau kontrak memegang peranan yang sangat penting di dalam aspek kehidupan manusia, khususnya di dalam aktivitas yang berkaitan dengan perekonomian. Pembuatan perjanjian membutuhkan adanya itikad baik para pihak dalam membuat persetujuan dan kesepakatan. Janji yang dibuat para pihak yang dituangkan dalam bentuk perjanjian, idealnya harus dilaksanakan para pihak dalam rangka memenuhi prestasinya, namun dalam prakteknya, pemenuhan janji tersebut tidaklah selalu berjalan mulus. Salah satu upaya yang dilakukan para pihak di dalam menghindari pemenuhan prestasi dalam perjanjian adalah dengan cara mengajukan pembatalan perjanjian atau membuat supaya perjanjian tersebut dianggap cacat secara yuridis.

Suatu perjanjian yang dinyatakan batal demi hukum (Null and Void), mempunyai aspek hukum terhadap perjanjian yang telah dibuat para pihak, tidaklah lagi memiliki akibat hukum yang mengikat para pihak yang membuat perjanjian sebagai Undang-undang seperti yang diatur dalam Pasal 1338 KUH Perdata. Perjanjian yang telah dibuat tidak lagi berlaku atau dianggap tidak pernah ada dan dikembalikan pada keadaan semula seperti pada saat perjanjian belum dilaksanakan. Dimana pihak yang melakukan kesalahan bertanggung jawab untuk memulihkan/ men-

\footnotetext{
${ }^{1}$ Dosen Tetap FH UKI.
}

gembalikan keadaan seperti semula, dimana ia tidak boleh mengambil keuntungan dengan dibatalkannya perjanjian, sementara bagi pihak yang tidak melakukan kesalahan sedapat mungkin tidak mengalami kerugian akibat pembatalan perjanjian.

\section{Permasalahan}

1. Apakah yang menjadi dasar suatu perjanjian dinyatakan batal demi hukum?

2. Bagaimana implementasi perjanjian dinyatakan batal demi hukum oleh hakim?

\section{Tujuan Penulisan}

1. Untuk mengetahui dasar perjanjian dinyatakan batal demi hukum.

2. Untuk mengetahui implementasi suatu perjanjian dinyatakan batal demi hukum oleh hakim.

\section{Persyaratan Sahnya Perjanjian dan Akibat Hukumnya}

Syarat sahnya suatu perjanjian diatur dalam Pasal 1320 KUH Perdata. Menurut Prof. Subekti perjanjian yang dibuat oleh para pihak harus memenuhi persyaratan sahnya suatu perjanjian, baik syarat subyektif dan syarat obyektif, yaitu: ${ }^{3}$

1. Sepakat mereka yang mengikatkan dirinya

2. Kecakapan dalam membuat perjanjian

3. Mengenai suatu hal tertentu 


\section{Suatu sebab yang halal}

Persyaratan no 1 dan 2 merupakan persyaratan subyektif dalam perjanjian, karena mengenai subyek atau orang yang mengadakan perjanjian, sedangkan persyaratan no 3 dan 4 merupakan syarat obyektif dalam perjanjian, karena mengenai obyek perjanjian atau perikatan hukum yang terjadi. Apabila salah satu unsur dalam perjanjian yang dibuat tidak dipenuhi akan memberikan akibat hukum yang berbeda. Tidak dipenuhinya syarat subyektif akan berakibat hukum perjanjian dapat dibatalkan atau perjanjian dapat dimintakan pembatalannya di pengadilan. Sedangkan tidak dipenuhinya syarat obyektif dalam perjanjian akan berakibat hukum perjanjian menjadi batal demi hukum atau perjanjian menjadi tidak dapat dituntut pemenuhan prestasinya atau perjanjian dianggap tidak pernah ada, dan tidak pernah terjadi perikatan hukum.

Subekti menyatakan bahwa perjanjian yang dibuat oleh para pihak harus memenuhi persyara- tan sahnya suatu perjanjian, baik syarat subyektif dan syarat obyektif seperti yang diatur dalam pasal 1320 KUH Perdata. Tidak dipenuhinya persyaratan subyektif menyebabkan perjanjian dapat dibatalkan (cancelling), yang dapat diajukan oleh para pihak yang tidak cakap, atau pihak yang merasa tidak bebas dalam membuat kesepakatan. Dalam hal ini perjanjian yang dibuat tetap mengikat, selama tidak dibatalkan oleh hakim atas permintaan salah satu pihak yang berhak meminta pembatalan perjanjian.

Sedangkan tidak dipenuhinya syarat obyektif, perjanjian batal demi hukum (null and void), perjanjian dianggap tidak pernah lahir dan tidak pernah terjadi suatu perikatan. Secara yuridis dianggap tidak pernah terjadi perjanjian maupun perikatan hukum, maka tertutup kemungkinan untuk menuntut pemenuhan prestasi oleh salah satu pihak di peradilan karena tidak ada dasar hukumnya.

\section{Perjanjian yang Dapat Dibatalkan}

Perjanjian yang dibuat para pihak yang memenuhi unsur sahnya perjanjian, pada dasarnya

\footnotetext{
${ }^{2}$ Ronny Hanitijo Soemitro, Metode Penelitian Hukum dan Jurimetri, Ghalia Indonesia, Jakarta, 1988, hal. 11.

${ }^{3}$ Subekti, Hukum Perjanjian, Cetakan ke-17, Intermasa, Jakarta, 2001, hal. 17
}

dapat dibatalkan oleh para pihak, apabila di dalam pelaksanaan perjanjian membuat para pihak mengalami kerugian, baik pihak yang terikat dalam perjanjian maupun pihak ketiga yang berada di luar perjanjian. Perjanjian yang dibuat dapat dibatalkan baik pada saat prestasi belum dilakukan, maupun setelah prestasi dilakukan.

Gunawan Widjaja ${ }^{4}$ memberikan alasan pembatalan suatu perjanjian, dengan membedakan menjadi:

a. Pembatalan perjanjian oleh salah satu pihak dalam perjanjian. Pembatalan ini sepihak ini terkait dengan tidak terpenuhinya persyaratan subyektif sahnya perjanjian. Permintaan pembatalan perjanjian dapat dilakukan apabila:

1) Tidak adanya kesepakatan bebas dari para pihak yang membuat perjanjian, baik karena terjadi kekhilafan, paksaan maupun penipuan oleh salah satu pihak pada saat perjanjian dibuat (Pasal 1321 sampai dengan Pasal 1328 KUH Perdata). Dalam hal ini pihak yang merasa dirugikan memiliki hak untuk meminta pembatalan perjanjian.

2) Adanya ketidakcakapan salah satu pihak dalam membuat perjanjian dan / atau tidak mempunyai kewenangan dalam melakukan tindakan hukum tertentu (Pasal 1330 dan Pasal 1331). Dalam hal ini pihak yang tidak cakap atau wakilnya yang sah berhak untuk meminta pembatalan perjanjian (Pasal 1446 sampai dengan Pasal 1450 KUH Perdata).

b. Pembatalan perjanjian oleh pihak ketiga di luar perjanjian.

Suatu perjanjian yang dibuat mengikat para pihak dan memiliki akibat hukum sebagai undang-undang bagi para pihak yang membuatnya, namun demiki- an pihak ketiga juga dilindungi oleh hukum, dimana pihak ketiga tersebut dapat mengajukan pembatalan perjanjian yang dibuat oleh pihak tertentu, sebagaimana yang diatur dalam Pasal 1341 ayat (1) KUH Perdata.

Pihak ketiga yang dimaksud sesuai dengan Pasal 1315 KUH Perdata adalah mereka yang bukan merupakan pihak dalam suatu perjanjian dan juga bukan penerima dan pengoper hak, baik berupa alas hak umum maupun alas hak khusus. ${ }^{5}$ Namun berdasar-

\footnotetext{
${ }^{4}$ Gunawan Widjaja, Perikatan yang Lahir dari Perjanjian, Jakarta: Raja Grafindo Persada, 2004, hal. 172.
} 
kan Pasal 1315 KUH Perdata jo Pasal 1340 ayat (2) KUH Perdata, tidak serta merta pihak ketiga setelah mengajukan pembatalan akan mendapatkan hak-haknya dalam pembatalan perjanjian tersebut, selain apa yang diatur di dalam Pasal 1317 KUH Perdata yaitu perjanjian untuk pihak ketiga.

Undang-undang juga memberikan hak kepada setiap kreditur yang disebut action paulina untuk menuntut kebatalan dari setiap tindakan debitur yang tidak diwajibkan, asalkan dapat dibuktikan pada saat tindakan hukum tersebut dilakukan debitur atau orang lain dimana debitur mengikat diri dan bahwa karena tindakan tersebut menyebabkan kerugian kreditur. ${ }^{6}$

\section{Perjanjian Batal Demi Hukum}

Mengenai maka akan dijelaskan terlebih dahulu pengertian "batal" dan pengertian "batal demi hukum" dalam.

Batal adalah: (1) tidak berlaku; tidak sah: perjanjian itu dinyatakan --; (2) tidak jadi dilangsungkan; ditunda; urung: rapat kemarin terpaksa -- karena yang hadir kurang dari dua pertiga jumlah anggota; (3) tidak berhasil; gagal. Dengan demikian, batal atau menyatakan batal artinya perjanjian yang pernah disetujui bersama tidak sah atau tidak terjadi. ${ }^{7}$ Sedangkan batal demi hukum adalah kebatalan yang terjadi berdasarkan undang-undang, berakibat perbuatanhukum yang bersangkutan tidak pernah terjadi ${ }^{8}$.

Dengan demikian, batal demi hukum (void) adalah kontrak yang tidak boleh dijalankan atau diselesaikan sama sekali. Bila sebuah kontrak dinyatakan batal demi hukum sejak awal (Latin: ab initio) berarti semua pihak harus meletakkan segala sesuatu seperti semula sebelum kontrak. Kontrak batal demi hukum bila salah satu pihak tidak memiliki kapasitas untuk melakukan kontrak, berdasarkan pada suatu kesalahan, atau melawan hukum. ${ }^{9}$

Dalam hal suatu perjanjian dinyatakan batal demi hukum, seorang Hakim diwajibkan, oleh karena jabatannya menyatakan bahwa suatu perjanjian tidak pernah lahir atau adanya suatu perikatan hukum. Perjan-

jian yang batal demi hukum, memiliki akibat yuridis berupa kebatalan mutlak, karena kebatalan tersebut

\footnotetext{
${ }^{5}$ J. Satrio, Hukum Perikatan, Perikatan yang Lahir dari Perjanjian, Bandung: Citra Aditya Bakti, 2001, hal. 90.

${ }^{6}$ Tan Thong Kie, Studi Notariat dan Serba Serbi Praktek Notaris, Jakarta: Ichtiar Baru Van Hoeve, 2007, hal. 415.
}

berlaku secara umum kepada semua pihak, berbeda dengan kebatalan relatif yang memiliki akibat hukum hanya pada pihak tertentu saja.

\section{Dasar Hukum Suatu Perjanjian Dinyatakan Ba- tal Demi Hukum}

Elly Erawati dan Herlien Budiono ${ }^{10}$, mengemukakan alasan-alasan yang dapat dijadikan sebagai dasar suatu perjanjian dikategorikan batal demihukum, yaitu:

1. Batal demi hukum karena syarat perjanjian formil tidak terpenuhi

2. Batal demi hukum karena syarat obyektif sahnya perjanjian tidak terpenuhi

3. Batal demi hukum karena dibuat oleh orang yang tidak berwenang melakukan perbuatan hukum

4. Batal demi hukum karena ada syarat batal yang terpenuhi.

KUH Perdata mengatur mengenai batal demi hukum di dalam beberapa pasal, yaitu:

a. Pasal 617 ayat (1) KUH Perdata yang menyatakan bahwa:

"Tiap-tiap akta dengan mana kebendaan tak bergerak dijual, dihibahkan, dibagi, dibebani, atau dipindahtangankan, harus dibuat dalam bentuk otentik, atas ancaman kebatalan".

b. Pasal $1254 \mathrm{KUH}$ Perdata yang menyatakan bahwa:

"Jika perjanjian memuat syarat yang bertujuan melakukan sesuatu yang tak mungkin terlaksana, atau yang bertentangan dengan kesusilaan yang baik, atau bahkan dilarang oleh undang-undang adalah batal demi hukum, ....".

c. Pasal 1256 KUH Perdata yang menyatakan bahwa:

"Semua perikatan adalah batal, jika pelaksanaannya semata-mata tergantung pada kemauan orang yang terikat,...."

d. Pasal 1265 KUH Perdata yang menyatakan bahwa: 
"Suatu syarat batal adalah syarat yang bila dipenuhi akan menghapuskan perikatan dan membawa segala sesuatu kembali pada keadaan semula, seolah-olah tidak pernah ada suatu perika$\tan "$.

e. Pasal 1335 KUH Perdata yang menyatakan bahwa:

"Suatu perjanjian tanpa sebab, atau yang telah dibuat karena suatu sebab yang palsu atau terlarang, tidak mempunyai kekuatan".

Pengertian "tidak mempunyai kekuatan" dalam pasal 1335 KUH Perdata ini dianggap batal demi hukum.

f. Pasal 1337 KUH Perdata yang menyatakan bahwa:

"Suatu sebab adalah terlarang, apabila dilarang oleh undang-undang, atau apabila berlawanan dengan kesusilaan atau ketertiban umum".

g. Pasal 1682 KUH Perdata yang menyatakan bahwa:

"Tiada suatu hibah, kecuali yang disebutkan dalam Pasal 1687, dapat atas ancaman batal, dilakukan selainnya dengan status akta notaris yang aslinya disimpan oleh notaris itu".

Selain diatur dalam KUH Perdata terdapat beberapa undang-undang yang secara eksplisit, yang menyebabkan suatu perjanjian dianggap batal demi hukum, yaitu: ${ }^{11}$

1) Pasal 21 ayat (2) dan Pasal 26 ayat (2) UU No. 5 tahun 1960 tentang Peraturan Dasar Pokokpokok Agraria.

2) Pasal 124 ayat (3) dan Pasal 127 ayat (1) UU No. 13 tahun 2003 tentang Ketenagakerjaan.

3) Pasal 12 dan Pasal 20 ayat (4) UU No. 4 Tahun 1996 tentang Hak Tanggungan atas Tanah Beserta Benda-benda yang Berkaitan dengan Tanah.

4) Pasal 32 dan Pasal 33 UU No. 42 tahun 1999 tentang Jaminan Fidusia.

5) Pasal 18 ayat (3) UU No. 8 tahun 1999 tentang Perlindungan Konsumen.

6) Pasal 33 ayat (1) dan (2) UU No. 25 tahun 2007 tentang Penanaman Modal.

7) Pasal 7 butir 1 dan 37 ayat (2) dan (3) UU No. 40 tahun 2007 tentang Perseroan Terbatas.

8) Pasal 27 ayat (1) dan (2) UU No. 25 tahun 2009 tentang Pelayanan Publik.
9) Pasal 66 ayat (1), (2), (3) dan (4) UU No. 14 tahun 2001 tentang Paten.

10) Pasal 55 ayat (4) dan (5) dan Pasal 56 ayat (1) dan (2) UU No. 23 tahun 1999 tentang Bank Indonesia.

11) Pasal 5 butir 1 UU No. 42 tahun 1999 tentang Jaminan Fidusia.

12) Pasal 9 UU No. 30 tahun 1999 tentang Arbitrase dan Alternative Penyelesaian Sengketa.

13) Pasal 15 ayat (1) UU No. 4 tahun 1996 tentang Hak Tanggungan atas Tanah Beserta Benda-benda yang Berkaitan dengan Tanah.

\section{Implementasi Perjanjian Dinyatakan Batal Demi Hukum Oleh Hakim}

Dalam prakteknya Hakim di dalam memutuskan apakah suatu perjanjian batal demi hukum, biasanya dengan cara menafsirkan norma hukum dalam suatu perkara hukum dengan mengkaji dan menafsirkan isi perjanjian yang dibuat oleh para pihak.

Putusan Mahkamah Agung Republik Indonesia terkait dengan amar putusan yang menyatakan perjanjian batal demi hukum, beserta analisa yuridis, adalah sebagai berikut: ${ }^{12}$

1. Putusan MARI No. 3597K/PDT/1985 tanggal 27 November 1984

Kaidah dan Dasar Hukum:

Jual beli dengan hak membeli kembali, merupakan bentuk perjanjian menurut Pasal 1519 dan seterusnya BW, sedangkan jual beli tanah atau rumah sesuai dengan UUPA dikuasai oleh hukum adat yang tidak mengenal bentuk jual beli dengan hak membeli kembali. Maka perjanjian penggugat dan tergugat dalam perkara ini adalah batal demi hukum.

Analisa Yuridis:

Perjanjian dinyatakan batal demi hukum, karena tidak terpenuhinya syarat obyektif perjanjian yaitu sebab yang halal.

2. Putusan MARI No.1873K/PDT/2001 tanggal 3 Oktober 2002

Kaidah dan Dasar Hukum:

Akta yang dalam pembuatannya mengandung cacat kehendak dan juga penipuan, dinyatakan batal demi hukum.

${ }^{11}$ Ibid, hal. 10-46. 
Kaidah dan Dasar Hukum:

Perjanjian dinyatakan batal demi hukum, kare- na tidak terpenuhinya syarat obyektif perjanjian causa/ sebab yang halal.

3. Putusan MARI No. 1400K/PDT/2001 tanggal 2 Januari 2003

Kaidah dan Dasar Hukum:

Barang jaminan hanya dijual melalui lelang, bank tidak berhak menjual sendiri tanah yang dijaminkan kepada bank, tanpa seijin pemilik. Pengalihan hak atas tanah berdasarkan surat kuasa mutlak batal demi hukum.

Analisa Yuridis:

Perjanjian dinyatakan batal demi hukum, kare- na tidak terpenuhinya syarat obyektif perjanjian mengenai sebab yang halal dalam hal ini melanggar peraturan yang berlaku, yaitu Instruksi Mendagri No. 14 tahun 1982.

4. Putusan MARI No. 5072K/PDT/1998 tanggal 29 September 2003

Kaidah dan Dasar Hukum:

Perjanjian jual beli atas suatu obyek yang kepemilikannya belum pasti adalah batal demi hukum, karena tanpa alas hak yang sah dan tidak memenuhi syarat halalnya dasar perjanjian.

Analisa Yuridis:

Perjanjian dinyatakan batal demi hukum, kare- na tidak terpenuhinya syarat obyektif perjanjian mengenai sebab yang halal.

5. Putusan MARI No. 698PK/PDT/2001 tanggal 27 Februari 2003

Kaidah dan Dasar Hukum:

Secara yuridis tertanggung mempunyai kewajiban untuk memberitahukan keadaan yang sebenarnya dari kapal yang akan diasuransikan, jika ternyata ada yang disembunyikan pada waktu penutupan polis asuransi, maka perjanjian asuransi batal demi hukum.

Analisa Yuridis:

\footnotetext{
${ }^{12} \mathrm{http} / / /$ putusan.mahkamahagung.go.id/, diunduh pada tanggal 20 Maret 2016, jam 12.00
}

Perjanjian dinyatakan batal demi hukum, kare- na tidak terpenuhinya syarat obyektif perjanjian mengenai hal tertentu.

6. Putusan MARI No.2333K/PDT/2005 tanggal 30 Mei 2006.

\section{Kaidah dan Dasar Hukum:}

Perjanjian hibah tanah antara orang tua dan anakanaknya batal demi hukum, apabila tanah obyek hibah sudah diperjual belikan dan menjadi hak milik pihak lain.

Analisa Yuridis:

Perjanjian dinyatakan batal demi hukum, kare- na tidak terpenuhinya syarat obyektif perjanjian mengenai causa atau sebab yang halal yang melanggar peraturan perundang-undangan yang berlaku.

7. Putusan MARI No.406K/PDT/2007 tanggal 15 Agustus $2008^{13}$

\section{Kaidah dan Dasar Hukum:}

Perjanjian yang tidak ada obyeknya harus batal demi hukum.

Analisa Yuridis:

Perjanjian dinyatakan batal demi hukum, kare- na tidak terpenuhinya syarat obyektif perjanjian mengenai suatu hal tertentu.

8. Putusan MARI No. 13/PK/Pdt.Sus/2007 tanggal 17 Desember 2007

Kaidah dan Dasar Hukum:

Perjanjian pengalihan piutang (cessie) CV dengan Bank Nasional yang diambil alih oleh BPPN yang kemudian di ambil oleh Bank Swasta, membuat perjanjian pengalihan piutang menjadi tidak sah dan batal demi hukum.

Analisa Yuridis:

Perjanjian pengalihan piutang dinyatakan batal demi hukum, karena tidak terpenuhinya syarat obyektif perjanjian mengenai suatu causa/ sebab yang halal yaitu bertentangan dengan UU, apakah pengalihan tersebut berdasarkan subrogasi

\footnotetext{
${ }^{13}$ Elly Erawati dan Herlien Budiono, Penjelasan Hukum Tentang Kebatalan Perjanjian, Loc.cit hal. 100.
} 
dimana pengantian hak pihak berpiutangoleh pihak ketiga yang membayar kepada si berpiutang seperti yang diatur Pasal 1400 KUH Perdata ataukah berdasarkan cessie atau pemindahan suatu piutang kepada seseorang yang telah membeli piutang tersebut.

9. Putusan No.29/Pdt.G/2012/PN.Jkt.Brt tanggal 25 Januari 2012

Kaidah dan Dasar Hukum:

Perjanjian pembiayaan konsumen dibuat dengan adanya cacat hukum, dimana obyek pembiayaan konsumen telah menjadi milik sebelum adanya perjanjian konsumen sehingga tidak memenuhi syarat sah perjanjian oleh karenanya perjanjian dianggap tidak sah dan harus batal demi hukum. Analisa Yuridis:

Perjanjian dinyatakan batal demi hukum, kare- na tidak terpenuhinya syarat obyektif perjanjian mengenai suatu causa/ sebab yang halal, seperti dalam Pasal 1320 KUH Perdata.

10. Putusan MARI No. 34/PDT/2012/PT.SBY tanggal 12 Maret 2012

Kaidah dan Dasar Hukum:

Perjanjian jual beli dengan hak membeli kembali, dengan harga membeli kembali yang lebih besar dari harga pada saat dijual disertai dengan bunga yang lebih besar dari 6\%/ tahun, dinyatakan batal demi hukum dan tidak memiliki kekuatan mengikat lagi.

Analisa Yuridis:

Perjanjian dinyatakan batal demi hukum, kare- na tidak terpenuhinya syarat obyektif perjanjian mengenai sebab yang halal, yaitu Bunga Moratoir merupakan ganti rugi dalam wujud sejumlah uang, sebagai akibat dari tidak atau terlambat dipenuhinya perikatan yang berisi kewajiban pembayaran sejumlah uang oleh debitur yang diatur khusus pada Pasal 1250 paragraf (1) KUHPerdata, dimana bunga yang ditentukan berdasarkan undang-undang adalah bunga sebesar $6 \%$ persen setahun, hal ini dilihat dari S.1848: No. 22.
11. Putusan No.95/Pdt.G/2013/PN.PLG tanggal 29 November 2012

Kaidah dan Dasar Hukum:

Perjanjian akta hibah yang kemudian hak dialihkan kepada orang lain dengan perjanjian jual beli saham merupakan perbuatan melawan hukum, sehingga perjanjian jual beli saham dinyatakan batal demi hukum

Analisa Yuridis:

Perjanjian dinyatakan batal demi hukum, kare- na tidak terpenuhinya syarat obyektif perjanjian mengenai suatu causa/ sebab yang halal, yaitu bertentangan dengan UU Perseroan Terbatas.

12. Putusan No. 22/Pdt/ 2012/PT.JBI tanggal 8 Agustus 2012

\section{Kaidah dan Dasar Hukum:}

Pembuatan surat kuasa untuk menjual karena ahli waris tidak diketahui keberadaanya dan dianggap hilang yang diajukan ke Pengadilan Negeri oleh salah satu saudara sekandung ahli waris dibuatkan ktp dengan foto dirinya sendiri, tanpa seizin ahli waris lainnya adalah tidak sah oleh karenanya akta perjanjian jual beli dengan pihak ketiga adalah batal demi hukum.

Analisa Yuridis:

Perjanjian dinyatakan batal demi hukum, kare- na tidak terpenuhinya syarat obyektif perjanjian mengenai suatu causa/ sebab yang halal, karena perolehan surat kuasa menjual tidak pernah ada dari ahli waris dan juga pengajuan dirinya sebagai ahli waris dari saudara sekandung tanpa izin dari ahli waris lainnya adalah batal demi hukum.

13. Putusan No.85/Pdt.G/2013/PN.Klaten tanggal 14 Agustus 2014

Kaidah dan Dasar Hukum:

Peralihan hak dengan akta jual beli atas barang sengketa berupa tanah dan rumah warisan yang belum dibagi dan tanpa persetujuan para ahli waris adalah batal demi hukum. 
Analisa Yuridis:

Perjanjian dinyatakan batal demi hukum, kare- na tidak terpenuhinya syarat obyektif perjanjian mengenai suatu causa/ sebab yang halal.

14 Putusan No. 442/Pdt/2014/PT.DKI tanggal 23 Juni 2014

Kaidah dan Dasar Hukum:

Perjanjian akta pengikatan perjanjian jual beli (PPJB) tanah dan bangunan yang tidak menyertakan keseluruhan ahli waris yang dijadikan sebagai obyek hak tanggungan bank adalah cacat hukum dan oleh karenanya dinyatakan batal demi hukum.

Analisa Yuridis:

Perjanjian dinyatakan batal demi hukum, kare- na tidak terpenuhinya syarat obyektif perjanjian mengenai suatu causa/ sebab yang halal.

15 Putusan No. 347/Pdt.G/2014/PN.Dps tanggal 30 Oktober 2014

Kaidah dan Dasar Hukum:

Perjanjian jual beli tanah yang masih dalam sengketa adalah cacat hukum dan batal demi hukum Analisa Yuridis:

Perjanjian dinyatakan batal demi hukum, kare- na tidak terpenuhinya syarat obyektif perjanjian mengenai suatu causa/ sebab yang halal.

16. Putusan No. 11/Pdt.G/2015/PN.BSK tanggal 21 Januari 2016

Kaidah dan Dasar Hukum:

Perjanjian jual beli tanah pusaka tinggi (tanah ulayat) Kaum Rumah Kapalo Koto Persukuan Rumah Supanjang adalah cacat hukum dan batal demi hukum.

Analisa Yuridis:

Perjanjian dinyatakan batal demi hukum, kare- na tidak terpenuhinya syarat obyektif perjanjian mengenai suatu causa/ sebab yang halal yaitu bertentangan dengan Pasal 3, Pasal 2 ayat (4) Undang-Undang No. 5 tahun 1960 tentang Peraturan Dasar Pokok-pokok Agraria.

\section{Kesimpulan}

1. Tidak terpenuhinya syarat obyektif yang diatur dalam Pasal 1320 KUH Perdata yaitu, menge- nai suatu hal tertentu dan suatu sebab yang halal, membawa akibat yuridis suatu perjanjian dinyatakan batal demi hukum, berarti bahwa perjanjian menjadi tidak berlaku atau tidak sah berdasarkan hukum atau peraturan perundang-undangan yang berlaku.

2. Dari beberapa putusan Mahkamah Agung dan Hakim yang diperoleh, pada umumnya putusan Hakim yang menyatakan perjanjian dinyatakan batal demi hukum, oleh karena tidak dipenuhinya syarat obyektif yaitu suatu hal tertentu dan sebab yang halal, karena bertentangan dengan ketentuan peraturan perundang-undangan yang berlaku.

\section{Saran}

1. Para pihak dalam membuat perjanjian atau kontrak seharusnya memiliki itikad baik, sebagai unsur yang penting dalam perjanjian yang dibuat, sebagaimana yang diatur dalam Pasal 1338 ayat (3) KUH Perdata.

2. Hakim di dalam memeriksa dan memberikan putusan perjanjian dinyatakan batal demi hukum, harus berpegang pada prinsip syarat sahnya perjanjian yang telah disepakati para pihak yang diatur dalam Pasal 1320 KUH Perdata dan seminimal memberikan putusan batal demi hukum karena hal tersebut akan menimbulkan permasalahan baru dan juga akan merugikan pihak-pihak lain dimana dengan adanya putusan batal demi hukum, maka perjanjian dianggap tidak pernah lahir. 


\section{Daftar Pustaka}

\section{Buku}

Elly Erawati dan Herlien Budiono, Penjelasan Hu- kum Tentang Kebatalan Perjanjian, Jakarta: Gramedia, 2010.

Gunawan Widjaja, Perikatan yang Lahir dari Per- janjian, Jakarta: Raja Grafindo Persada, 2004.

J. Satrio, Hukum Perikatan, Perikatan yang Lahir dari Perjanjian, Bandung: Citra Aditya Bakti, 2001.

Ronny Hanitijo Soemitro, Metode Penelitian Hu- kum dan Jurimetri, Ghalia Indonesia, Jakarta, 1988. Subekti, Hukum Perjanjian, Cetakan ke-17, Interma- sa, Jakarta, 2001.

Tan Thong Kie, Studi Notariat dan Serba Serbi Prak- tek Notaris, Jakarta: Ichtiar Baru Van Hoeve, 2007.

\section{Peraturan Perundang-undangan}

Kitab Undang-undang Hukum Perdata

Undang-U No. 40 tahun 2007 tentang Perseroan Ter- batas.

Undang-Undang No. 4 Tahun 1996 tentang Hak Tan- ggungan atas Tanah Beserta Bendabenda yang Berkaitan dengan Tanah.

Undang-Undang No. 42 tahun 1999 tentang Jaminan Fidusia.

\section{Internet}

http://bahasa.kemdiknas.go.id/kbbi/index.php, diun- duh pada 21 Maret 2016, jam 12.30.

http://kamuslengkap.com/kamus/hukum/arti-kata/ Batal+demi+hukum, diunduh pada 21 Maret 2016, jam. 12.00.

http://kamusbisnis.com/arti/batal-demi-hukum/, diunduh pada 21 Maret 2016, jam. 12.00. http://putusan.mahkamahagung.go.id/, diunduh pada tanggal 20 Maret 